\title{
FAKTOR-FAKTOR YANG BERHUBUNGAN DENGAN SULIT MAKAN PADA ANAK USIA PRA SEKOLAH DI TK AT NURUS SHOLIHAH KEBAGUSAN PASAR MINGGU JAKARTA SELATAN
}

\author{
Lia Fitriyanti ${ }^{1}$, Imam Sutiejo ${ }^{2}$ \\ Program studi DIII Keperawatan Universitas MH. Thamrin Jakarta \\ lia_fy16@yahoo.com
}

\begin{abstract}
ABSTRAK
Latar belakang Anak prasekolah adalah anak yang berusia antara 3-5 tahun. Pada masa ini tentunya anak mengalami berbagai proses pertumbuhan dan perkembangan, pada masa ini pula anak biasanya mengalami perubahan pola makan dimana anak cenderung mengalami sulit makan. Sulit makan pada anak didefinisikan sebagai perilaku anak yang mengalami gangguan makan yang dapat berupa penolakan untuk makan sehingga berdamapak negatif pada tumbuh kembang anak, Kesulitan makan pada anak tentunya di pengaruhi oleh beberapa faktor diantaranya pendidikan ibu, pengetahuan ibu terhadap kebutuhan gizi anak, perkerjaan ibu serta sikap ibu. Tujuan Penelitian : untuk mengetahui gambaran perilaku sulit makan pada anak prasekolah dan untuk menganalisis faktor-faktor yang berhubungan dengan sulit makan pada anak usia pra sekolah. Metode: yang digunakan adalah metode pengumpulan data yang berupa kuesioner, dengan pendekatan cross-sectional, populasi diambil dari Tk At Nurus Sholihah Kebagusan dengan sample yang diambil sebanyak 40 responden. Hasil : pada analisis tersebut diperoleh data dimana perilaku sulit makan dialami oleh 24 responden $(60 \%)$. Hasil bivariat menunjukkan bahwa adanya hubungan yang signifikan antara sulit makan dengan pengetahuan ibu $(\mathrm{OR}=6.429 ; \mathrm{CI}=1.495-27.647, \mathrm{P}=0.023)$, status perkerjaan ibu $(\mathrm{OR}=5.343 ; \mathrm{CI}=1.350-21.144, \mathrm{P}=$ 0.032) dan sikap ibu $(\mathrm{OR}=6.333 ; \mathrm{CI}=1.543-26.003, \mathrm{P}=0.020)$. Kesimpulan: sulit makan pada anak dipengaruhi oleh sikap ibu yang kurang baik, pengetahuan ibu yang kurang dan ibu yang bekerja.
\end{abstract}

Kata Kunci: Anak, Prasekolah, Sulit makan

\section{PENDAHULUAN}

Sulit makan adalah ketidak mampuan anak untuk mengkonsumsi sejumlah makanan yang diperlukan atau penolakan makanan. Makan merupakan kegiatan rutin sehari-hari yang jika dilihat sepintas tampaknya sangat sederhana, tetapi makan adalah salah satu pemenuhan kebutuhan terhadap gizi baik untuk tumbuh kembang anak (Suedibyo, 2009).

Beberapa penelitian yang terkait dengan kesulitan makan pada anak pra sekolah telah dilakukan oleh banyak peneliti. Berdasarkan hasil penelitian yang di lakukan di negara Eropa di New Zealand dilaporkan sebanyak $24 \%$ responden menganggap anaknya memiliki masalah kesulitan makan di usia tiga tahun dan $18 \%$ diantaranya berlanjut hingga usia lima tahun. (UNICEF, 2013).

Hal yang senada, penelitian yang dilakukan di Jakarta menyatakan bahwa anak usia pra sekolah (3-5 tahun) didapatkan prevalesi kesulian makan yaitu sebesar 33,6\% dan $79,2 \%$ terjadi kesulitan makan yang lamanya lebih dari tiga bulan (Judarwanto, 2015

Berdasarkan hasil observasi pendahuluan yang dilakukan peneliti tanggal 16 Mei 2016 di Tk At Nurus Sholisah terletak di kelurahan kebagusan kecamatan pasar minggu Jakarta Selatan. Tk ini dibangun tahun 2007 oleh pemerintah yang terdiri dari 3 kelas dan mempunyi 7 orang guru tetap, jumlah murid keseluruhan sebanyak 50 murid. Setelah peneliti meminta izin kepada kepala sekolah untuk mewawancarai orang tua murid sebanyak 10 orang tua, menunjukan hasil bahwa 7 orang ibu (70\%) mengeluh mengalami kesulitan dalam memberikan makankepada anaknya dan 3 orang ibu (30\%) tidak mengalami kesulitan dalam memberikan makan pada anaknya. Selain itu peneliti juga mengamati sikap orang ibu yang membawakan bekal untuk anakanya tetapi ibu 
membiarkan anaknya untuk jajan sembarangan tampa menghiraukan kulitas makanan tersebut. Berdasarkan latar belakang diatas, maka peneliti tertarik untuk mengetahui "Faktor-faktor yang berhubungan dengan sulit makanan pada anak usia pra sekolah di Tk At Nurus Sholihah Kebagusan Pasar Minggu Jakarta Selatan, adapun tujuan penelitian ini adalah untuk mengetahuai faktor-faktor yang berhubungan dengan sulit makan pada anak usia pra sekolah di TK At Nurus SholihahKebagusan Pasar Minggu tahun 2016.

\section{METODE}

Penelitian ini dilakukan di Tk At Nurus Sholihah Kebagusan Pasar Minggu Jakarta Selatan. Adapun waktu Penelitian dilakukan pada tangal 27-29 Juli 2016.Jenis penelitian yang menggunakan deskriptif analitik dengan pendekatan kuantitatif dengan desain crosssectional, popolasi dalam penelitian ini adalah semua anak Tk yang berusia 3-5 tahun. Penelitian ini menggunakan teknik purposive sampling yaitu memlalui kriteria inklusidan eksklusi, sampel penelitian berjumlah 40 responden (Dharma, 2011).Peneliti menggunakan alat pengumpulan data berupa kuesioner, metode kuesioner adalah metode pengumpulan data dengan cara memberikan daftar pertanyaan tertulis dengan beberapa pilihan jawaban kepada responden. Metode kuesioner tidak harus peneliti untuk bertatap muka langsung dengan responden, karena semua petunjuk dan cara menjawab pertanyaan tertulis sudah tercantum semua didalam kuesioner (Dharma, 2011)

\section{HASIL DAN PEMBAHASAN}

\section{Analisa Univariat}

Berdasarkan tabel 1 diketahui bahwa dari 40 Responden, lebih banyak anak yang mengalami sulit makan yaitu sebanyak 24 anak atau $60 \%$.

\section{Tabel 1}

Distribusi Responden Menurut Sulit Makan Pada Anak Di Tk At Nurus Sholihah Kebagusan Pasar Minggu Jakarta Selatan Tahun 2016

\begin{tabular}{cccc}
\hline Variabel & & $\begin{array}{c}\text { Frekuensi } \\
(\mathrm{F})\end{array}$ & $\begin{array}{c}\text { Presentase } \\
(\%)\end{array}$ \\
\hline Sulit Makan & Ya & 24 & 60 \\
& Tidak & 16 & 40 \\
\hline Total & & 40 & 100.0 \\
\hline
\end{tabular}

Berdasarkan tabel 2 diketahui bahwa dari 40 responden, lebih banyak respoden berpendidikan tinggi yaitu sebanyak 26 responden atau $65 \%$.

Tabel 2

Distribusi Responden Menurut Pendidikan Ibu Di Tk At Nurus Sholihah Kebagusan Pasar Minggu Jakarta Selatan Tahun 2016

\begin{tabular}{ccc}
\hline $\begin{array}{c}\text { Variabel } \\
\text { Pendidikan }\end{array}$ & Frekuensi (F) & Presentase (\%) \\
\hline Rendah & 14 & 35 \\
Tinggi & 26 & 65 \\
\hline Total & $\mathbf{4 0}$ & $\mathbf{1 0 0 . 0}$ \\
\hline
\end{tabular}


Berdasarkan tabel 3 diketahui bahwa dari 40 responden, lebih banyak responden yang memiliki Pengetahuan kurang yaitu sebanyak 27 responden atau $67.5 \%$.

Tabel 3

Distribusi Responden Menurut Pengetahuan Ibu Di Tk At Nurus Sholihah Kebagusan Pasar Minggu Jakarta Selatan Tahun 2016

\begin{tabular}{lcc}
\hline $\begin{array}{c}\text { Variabel } \\
\text { Pengetahuan }\end{array}$ & $\begin{array}{c}\text { Frekuensi } \\
(\mathbf{F})\end{array}$ & Presentase $(\boldsymbol{\%})$ \\
\hline Kurang & 27 & 67.5 \\
Baik & 13 & 32.5 \\
\hline \multicolumn{1}{c}{ Total } & $\mathbf{4 0}$ & $\mathbf{1 0 0 . 0}$ \\
\hline
\end{tabular}

Berdasarkan tabel 4 diketahui bahwa dari 40 responden, lebih banyak ibu yang memiliki sikap kurang baik yaitu sebanyak 25 responden atau $62.5 \%$.

\section{Tabel 4}

Distribusi Responden Menurut sikap Ibu Di Tk At Nurus Sholihah Kebagusan Pasar Minggu Jakarta Selatan Tahun 2016

\begin{tabular}{ccc}
\hline Variabel & Frekuensi (F) & Presentase (\%) \\
Sikap & 25 & 62.5 \\
Kurang & 15 & 37.5 \\
Baik & $\mathbf{4 0}$ & $\mathbf{1 0 0 . 0}$ \\
\hline Total & & \\
\hline
\end{tabular}

Berdasarkan tabel 5 diketahui bahwa dari 40 responden, lebih banyakresponden yangbekerja yaitu sebanyak 22 responden atau $55 \%$.

Tabel 5

Distribusi Responden Menurut Pekerjaan Ibu Di Tk At Nurus Sholihah Kebagusan Pasar Minggu Jakarta Selatan Tahun 2016

\begin{tabular}{ccc}
\hline $\begin{array}{c}\text { Variabel } \\
\text { Bekerja }\end{array}$ & Frekuensi $(\mathbf{F})$ & Presentase $(\boldsymbol{\%})$ \\
\hline Ya & 22 & 55 \\
Tidak & 18 & 45 \\
\hline Total & $\mathbf{4 0}$ & $\mathbf{1 0 0 . 0}$ \\
\hline
\end{tabular}

\section{Analisa Bivariat}

Berdasarkan tabel 6 hasil analisis hubungan antara pendidikan ibu dengan perilaku sulit makan pada anak usia pra sekolah diperoleh bahwa di antara 14 responden yang berpendidikan rendah, terdapat9 (64.3\%) responden yang memiliki anak dengan perilaku sulit makan. Sedangkan di antara 26 responden yang berpendidikan tinggi, terdapat $15(57.7 \%)$ responden yang memiliki anak dengan perilaku sulit makan. Dari hasil uji statistik didapatkan nilai p value sebesar 0.946 dan OR sebesar 1.320 artinya tidak terdapat hubungan yang bermakna antara pendidikan ibu dengan perilaku sulit makan pada anak. Hal ini senada dengan penelitian Dani (2011) menunjukan bahwa tidak ada hubungan antara pendidikan ibu dengan sulit makan pada anak. 
Dengan hasil penelitian $p$ value $=0.397>0.05$ artinya tidak ada hubungan antara pendiddikan terhadap sulit makan pada anak penelitian tersebut senada dengan penelitian yang dilakukan oleh Powell, Farrow dan Myer (2016) yang menyatakan pendidikan ibu tidak berpengaruh dalam masalah kesulitan makan pada anak dengan hasil $p$ value $=0.549>0.05$ yang artinya tidak terdapat hubungan antara pendidikan ibu terhadap sulit makan pada anak. Hal ini dimungkinkan karena ada faktor lain yang mempengaruhi seperti kesibukan dan pekerjaan. Meski ibu berpendidikan tinggi, namun karena kesibukannya dalam bekerja sehingga membuatnya tidak dapat memberikan perhatian lebih kepada anak-anaknya. Selain itu, dimungkinkan juga karena pendidikan yang tinggi tersebut tidak diikuti pengetahuan di bidang gizi (Suhardjo, 2013). Peneliti berasumsi bahwa pendidikan ibu merupakan faktor secara tidak langsung yang dapat mempengaruhi kejadian sulit makan pada anak. Namun pendidikan harus dibarengin dengan pengatahuan tentang gizi yang baik, apabila pendidikan tinggi tidak dibarengin dengan pengatahuan gizi yang baik maka ibu beresiko memiliki anak berperilaku sulit.

Tabel 6

Distribusi Hubungan Pendidikan Ibu Dengan Kejadian Sulit Makan Pada Anak Di Tk At Nurus Sholihah Kebagusan Pasar Minggu Jakarta Selatan Tahun 2016

\begin{tabular}{|c|c|c|c|c|c|}
\hline \multirow{3}{*}{$\begin{array}{c}\text { Variabel } \\
\text { Pendidikan }\end{array}$} & \multicolumn{2}{|c|}{ Sulit Makan } & \multirow[b]{2}{*}{ Total } & \multirow{3}{*}{$P$ Value } & \multirow{3}{*}{$\begin{array}{c}\text { OR }(95 \% \\
\text { confidence } \\
\text { Interval) }\end{array}$} \\
\hline & Ya & Tidak & & & \\
\hline & F $(\%)$ & $\mathbf{F}(\%)$ & $\begin{array}{c}\mathbf{F} \\
(\%)\end{array}$ & & \\
\hline Rendah & $\begin{array}{c}9 \\
(64.3)\end{array}$ & $\begin{array}{c}5 \\
(35.7)\end{array}$ & $\begin{array}{c}14 \\
(100)\end{array}$ & & 1.320 \\
\hline Tinggi & $\begin{array}{c}15 \\
(57.7)\end{array}$ & $\begin{array}{c}11 \\
(42.3)\end{array}$ & $\begin{array}{c}26 \\
(100)\end{array}$ & 0.946 & $(0.345-5.050)$ \\
\hline Total & $\begin{array}{c}24 \\
(60)\end{array}$ & $\begin{array}{c}16 \\
(40)\end{array}$ & $\begin{array}{c}40 \\
(100)\end{array}$ & & \\
\hline
\end{tabular}

Berdasarkan tabel 7 hasil analisis hubungan antara pengetahuan ibu dengan perilaku sulit makan pada anak usia pra sekolah diperoleh bahwa di antara 27 responden berpengetahuan kurang, terdapat 20 (74.1\%) responden yang memiliki anak dengan perilaku sulitan makan pada anak. Sedangkan di antara 13 responden yang berpengetahuan baik, terdapat 4 (30.8\%) responden yang memiliki anak dengan kesulitan makan. Dari hasil uji statistik didapatkan nilai $\mathrm{p}$ value sebesar 0.023 dan OR sebesar 6.429 artinya terdapat hubungan yang bermakna antara pengetahuan ibu tentang gizi dengan kesulitan makan pada anak atau dapat disimpulkan ibu yang memiliki pengetahuan kurang tentang gizi berpeluang 6.429 kali lebih besar memiliki anak sulit makan dari pada ibu yang memiliki pengetahuan terhadap gizi baik. Hasil penelitian ini sejalan dengan penelitian yang dilakukan oleh Rosidi (2010) menyatakan bahwa pengetahuan ibu terhadap gizi berpengaruh signifikan terhadap kesulitan makan pada anak. Didapatkan hasil penelitian sebesar $p$ value $=0.003<0,05$, artinya didapat hubungan yang bermakna antara pengetahuan gizi dengan tindakan ibu dalam menyikapi sulit makan pada anak. Hal serupa penelitian yang dilakukan dengan oleh Millah (2013) terdapat $p$ value $=0.001$ yang artinya terdapat hubungan yang bermakna antara pengetahuan ibu terhadap sulit makan pada anak. Peneliti berasumsi bahwa pengetahuan ibu yang kurang baik dapat diakibatkan oleh kurangnya informasi mengenai kebutuhan gizi pada anak prasekolah. Ibu dengan pengetahua kurang tentang gizi cenderung membiarkan anaknya mengkonsumsi makanan ringan saja. Jadi sang anak mulai terbiasa dengan makanan yang ia sukai namun tidak dapat 
mencukupi kebutuhan gizinya. Maka dari itu ibu yang memiliki pengetahuan kurang cenderung beresiko memiliki anak yang sulit makan.

Tabel 7

Distribusi Hubungan Pengetahuan Ibu Dengan Kejadian Sulit Makan Pada Anak Di Tk At Nurus Sholihah Kebagusan Pasar Minggu Jakarta Selatan Tahun 2016

\begin{tabular}{|c|c|c|c|c|c|}
\hline \multirow{3}{*}{$\begin{array}{c}\text { Variabel } \\
\text { Pengetahuan }\end{array}$} & \multicolumn{2}{|c|}{ Sulit Makan } & \multirow{2}{*}{ Total } & \multirow{3}{*}{$\begin{array}{c}P \\
\text { Value }\end{array}$} & \multirow{3}{*}{$\begin{array}{c}\text { OR }(95 \% \\
\text { Confidence } \\
\text { Interval) }\end{array}$} \\
\hline & Ya & Tidak & & & \\
\hline & F (\%) & $\mathrm{F}(\%)$ & F (\%) & & \\
\hline \multirow[t]{2}{*}{ Kurang } & 20 & 7 & 27 & \multirow{3}{*}{0.023} & \multirow{3}{*}{$\begin{array}{c}6.429(1.495 \\
27.647)\end{array}$} \\
\hline & (74.1) & (25.9) & $(100)$ & & \\
\hline Baik & $\begin{array}{c}4 \\
(30.8)\end{array}$ & $\begin{array}{c}9 \\
(69.2)\end{array}$ & $\begin{array}{c}13 \\
(100)\end{array}$ & & \\
\hline Total & $\begin{array}{c}24 \\
(60)\end{array}$ & $\begin{array}{c}16 \\
(40)\end{array}$ & $\begin{array}{c}40 \\
(100) \\
\end{array}$ & & \\
\hline
\end{tabular}

Berdasarkan tabel 8 hasil analisis hubungan antara pengetahuan ibu dengan perilaku sulit makan pada anak usia pra sekolah diperoleh bahwa di antara 27 responden berpengetahuan kurang, terdapat $20(74.1 \%)$ responden yang memiliki anak dengan perilaku sulitan makan pada anak. Sedangkan di antara 13 responden yang berpengetahuan baik, terdapat 4 (30.8\%) responden yang memiliki anak dengan kesulitan makan. Dari hasil uji statistik didapatkan nilai p value sebesar 0.023 dan OR sebesar 6.429 artinya terdapat hubungan yang bermakna antara pengetahuan ibu tentang gizi dengan kesulitan makan pada anak atau dapat disimpulkan ibu yang memiliki pengetahuan kurang tentang gizi berpeluang6.429 kali lebih besar memiliki anak sulit makan dari pada ibu yang memiliki pengetahuan terhadap gizi baik. Hasil penelitian ini sejalan dengan penelitian yang dilakukan oleh Rosidi (2010) menyatakan bahwa pengetahuan ibu terhadap gizi berpengaruh signifikan terhadap kesulitan makan pada anak. Didapatkan hasil penelitian sebesar $p$ value $=0.003<0,05$, artinya didapat hubungan yang bermakna antara pengetahuan gizi dengan tindakan ibu dalam menyikapi sulit makan pada anak.Hal serupa penelitian yang dilakukan denganoleh Millah (2013) terdapat $p$ value $=0.001$ yang artinya terdapat hubungan yang bermakna antara pengetahuan ibu terhadap sulit makan pada anak. Peneliti berasumsi bahwa pengetahuan ibu yang kurang baik dapat diakibatkan oleh kurangnya informasi mengenai kebutuhan gizi pada anak prasekolah. Ibu dengan pengetahua kurang tentang gizi cenderung membiarkan anaknya mengkonsumsi makanan ringan saja. Jadi sang anak mulai terbiasa dengan makanan yang ia sukai namun tidak dapat mencukupi kebutuhan gizinya. Maka dari itu ibu yang memiliki pengetahuan kurang cenderung beresiko memiliki anak yang sulit makan.

Berdasarkan tabel 8 hasil analisis hubungan antara sikap ibu dengan perilaku sulit makan pada anak usia pra sekolah diperoleh bahwa di antara 25 responden yang memiliki sikap kurang baik, terdapat 19 (76\%) responden yang memiliki anak dengan perilaku sulit makan. Sedangkan di antara 15 responden yang memiliki sikap baik, terdapat 5 (33.3\%) responden memiliki anak dengan perilaku sulit makan. Dari hasil uji statistik didapatkan nilai $\mathrm{p}$ value sebesar 0.020 dan OR sebesar 6.333 artinyaterdapat hubungan yang bermakna antara sikap ibu dengan kesulitan makan pada anak atau dapat disimpulkan ibu yang memiliki sikap kurang baik berpeluang 6.333 kali lebih besar memiliki anak sulit makan dari pada ibu yang bersikap baik. Penelitian senada yang dilakukan oleh Eka, (2012) mengatakan terdapat hubungan yang bermakana antara sikap ibu terhadap sulit 
makan pada anak. Sikap ibu memang sangat penting dalam memberikan makanan yang baik kepada anak sehingga anak dapat tumbuh dan berkembang dengan baik. Hasil penelitian ini didapatkan $p$ value $=0.006>$ 0.05 artinya terdapat hubungan yang signifikan antara sikap ibu terhadap sulit makan pada anak. Hal yang senada juga penelitian yang dilakukan oleh Hendra (2015) dimana faktor yang mempengaruhi kesulitan makan pada anak adalah sikap ibu tentang gizi dengan hasil penelitian di dapatkan $p$ value $=0.012<0,05$ yang artinya terdapat hubungan yang bermakna antara sikap ibu terhadap gizi dengan sulit makan pada anak dengan. Peneliti berasumsi bahwa sikap ibu yang kurang baik sangat berpengaruh bagi kesehatan makan anak, hal ini dikarenakan ibu yang memiliki sikap kurang baik cendrung tidak peduli pada asupan makanan yang diberikan kepada anak. Ketika anak susah diberi makan seharusnya ibu langsung mencari solusi agar anaknya mau makan tentunya tidak mengurangi zat gizi makanan tersebut, lain halnya bagi ibu yang mempunyai sikap kurang baik cendrung memberikan makanan yang anak sukai saja agar anaknya mau makan, tanpa memikirkan kandungan zat gizi yang baik untuk tumbuh kembang anak. Maka ibu yang memiliki sikap kurang baik terhadap gizi beresiko memiliki anak yang mengalami sulit makan.

Tabel 8

Distribusi Hubungan Sikap Ibu Dengan Kejadian Sulit Makan Pada Anak Di Tk At Nurus Sholihah Kebagusan Pasar Minggu Jakarta Selatan Tahun 2016

\begin{tabular}{|c|c|c|c|c|c|}
\hline \multirow{4}{*}{$\begin{array}{l}\text { Variabel } \\
\text { Sikap }\end{array}$} & \multirow{2}{*}{\multicolumn{2}{|c|}{ Sulit Makan }} & \multirow[b]{3}{*}{ Total } & \multirow{3}{*}{$\begin{array}{l}P \\
\text { Value }\end{array}$} & \multirow{3}{*}{$\begin{array}{l}\text { OR }(95 \% \\
\text { Confidence } \\
\text { Interval) }\end{array}$} \\
\hline & & & & & \\
\hline & Ya & Tidak & & & \\
\hline & F (\%) & F (\%) & F (\%) & & \multirow{5}{*}{$\begin{array}{l}6.333 \\
26.003)\end{array}$} \\
\hline \multirow[t]{2}{*}{ Kurang } & 19 & 6 & 25 & \multirow{4}{*}{0.020} & \\
\hline & (76) & (24) & (100) & & \\
\hline \multirow{2}{*}{ Baik } & 5 & 10 & 15 & & \\
\hline & $\begin{array}{c}5 \\
(33.3)\end{array}$ & $\begin{array}{c}10 \\
(66.7)\end{array}$ & $\begin{array}{c}15 \\
(100)\end{array}$ & & \\
\hline Total & $\begin{array}{c}24 \\
(60)\end{array}$ & $\begin{array}{c}16 \\
(40)\end{array}$ & $\begin{array}{c}40 \\
(100)\end{array}$ & & \\
\hline
\end{tabular}

Berdasarkan tabel 9 hasil analisis hubungan antara pekerjaan ibu dengan perilaku sulit makan pada anak usia pra sekolah diperoleh bahwa di antara 22 responden yang bekerja, terdapat 17 (77.3\%) responden yang memilik anak dengan sulit makan. Sedangkan di antara 18 respoden yang tidak bekerja, terdapat 7 (38.9\%) responden yang memiliki anak dengan sulit makan. Dari hasil uji statistik yang didapatkan nilai p value sebesar 0.032 dan nilai OR sebesar 5.343 artinya terdapat hubungan yang bermakna antara pekerjaan ibu dengan kesulitan makan anak atau dapat disimpulkan bahwa ibu yang bekerja berpeluang 5.343 kali lebih besar memiliki anak sulit makan dari pada ibu yang tidak bekerja. Hasil penelitian ini didukung oleh Penelitian yang dilakukan Purnawati (2012) menunjukakan adanya hubungan antara pekerjaan ibu terhadap sulit makan pada anak yang didapatkan hasil penelitian $p$ value $=0.011$ yang artinya terdapat hubungan yang bermakna antara pekerjaan ibu terhadap sulit makan pada anak. Hal yang senada penelitian Linda (2011) menunjukan ada hubungan yang signifikan antara pekerjaan ibu dengan kesulitan makan pada anak. Dimana hasil perhitungan chi square didapatkan $\mathrm{P}$ value $0,023<0,05$ artinya ada hubungan antara pekerjaan ibu dengan sulit makan pada anak. 
Tabel 9

Distribusi Hubungan Pekerjaan Ibu Dengan Kejadian Sulit Makan Pada Anak Di Tk At Nurus Sholihah Kebagusan Pasar Minggu Jakarta Selatan Tahun 2016

\begin{tabular}{|c|c|c|c|c|c|}
\hline \multirow{2}{*}{$\begin{array}{l}\text { Variabel } \\
\text { Bekerja }\end{array}$} & \multicolumn{2}{|c|}{ Sulit Makan } & \multirow[b]{2}{*}{$\begin{array}{c}\text { Total } \\
\text { F (\%) }\end{array}$} & \multirow[b]{2}{*}{$\begin{array}{c}P \\
\text { value }\end{array}$} & \multirow{2}{*}{$\begin{array}{c}\text { OR(95\% } \\
\text { Confidence } \\
\text { Interval) }\end{array}$} \\
\hline & $\frac{\text { Ya }}{\mathbf{F}(\%)}$ & $\begin{array}{l}\text { Tidak } \\
\text { F (\%) }\end{array}$ & & & \\
\hline $\mathrm{Ya}$ & $\begin{array}{c}17 \\
(77.3)\end{array}$ & $\begin{array}{c}5 \\
(22 .)\end{array}$ & $\begin{array}{c}22 \\
(100)\end{array}$ & & 5.343 \\
\hline Tidak & $\begin{array}{c}7 \\
(38.9)\end{array}$ & $\begin{array}{c}11 \\
(61 .)\end{array}$ & $\begin{array}{c}18 \\
(100)\end{array}$ & 0.032 & 21.144) \\
\hline Total & $\begin{array}{c}24 \\
(60)\end{array}$ & $\begin{array}{c}16 \\
(60)\end{array}$ & $\begin{array}{c}40 \\
(100)\end{array}$ & & \\
\hline
\end{tabular}

Peneliti berasumsi ibu yang bekerja lebih sedikit mempunyai waktu untuk bersama-sama terutama dalam memberi makan pada anak. Karna ibu sibuk dalam bekerja untuk memenuhi kebutuhan ekonomi keluarga. Ibu yang bekerja cendrung mempercayakan anaknya pada orang lain (pembantu). Berbeda halnya dengan ibu yang tidak bekerja, ibu lebih banyak memiliki waktu untuk anak dan lebih bisa mengontrol asupan makanan bagi anaknya.

\section{KESIMPULAN DAN SARAN}

Kesimpulan dibuat berdasarkan pada tujuan khusus dan hasil penelitian beserta analisis univariat dan bivariat dari jumlah 40 responden di TK AT Nurus Sholihah Kebagusan Pasar Minggu, adapun kesimpulan pada penelitian ini adalah : Hasil uji analisis univariat menunjukkan bahwa proporsi kejadian sulit makan pada anak di Tk At Nurus Sholihah Jakarta Selatan Tahun 2016 lebih banyak anak yang mengalami sulit makan sebesar 60\% (24 anak) dibandingkan anak yang tidak mengalami sulit makan sebesar 40\% (16 anak); Adanya hubungan yang signifikan antara tingkat pengetahuan ibu dengan kesulitan makan pada anak usia pra sekolah di Tk At Nurus Sholihah Jakarta Selatan Tahun 2016, yaitu dilihat dari hasil uji statistik didapatkan $p$-value = 0.023 dan nilai $\mathrm{OR}=6.429$; Adanya hubungan yang signifikan antara sikap ibu dengan kesulitan makan pada anak usia pra sekolah di Tk At Nurus Sholihah Jakarta Selatan Tahun 2016, yaitu dilihat dari hasil uji statistik didapatkan $p$-value $=0.020$ dan nilai $\mathrm{OR}=6.333$; Tidak adanya hubungan antara pendidikan ibu dengan kesulitan makan pada anak usia pra sekolah di Tk At Nurus Sholihah Jakarta Selatan Tahun 2016, yaitu dilihat dari hasil uji statistik didapatkan $p$-value $=0.946$ dan nilai $\mathrm{OR}=1.320$; Adanya hubungan yang signifikan pekerjaan ibu dengan kesulitan makan pada anak usia pra sekolah di Tk At Nurus Sholihah Jakarta Selatan Tahun 2016, yaitu dilihat dari uji statistik didapatkan $p$-value $=0.032$ dan nilai $\mathrm{OR}=5.343$. saran yang dapat diberikan peneliti yaitu Bagi Taman Kanak-Kanak Mengadakan program penyediaan makan yang bergizi sesuai kebutuhan anak. Dan mengadakan penyuluhan kepada ibu tentang gizi baik pada anak, sehingga ibu lebih mengerti dan memahami dalam hal menangani anak yang mengalami sulit makan. Bagi Orang Tua Memperkenalkan variasi makanan sejak dini pada anak, seperti memberikan selingan makan yang bergizi se perti buah-buahan, Susu dan lain-lain yang sesuai dengan kebutuhan gizi anak. Serta pembuatan makanan yang menarik bagi anak seperti makanan berbentuk binatang atau tokoh kartung yang dia senangi sehingga anak tertarik untuk mamakanya. Dan jangan lupa bersikap tegas mengenai asupan makanan pada anak dengan 
memberikan pengertian kepada mereka akan baik dan buruknya makanan yang akan dikonsumsi. Sehingga akan berdampak baik pada kebiasaan makan anak. Bagi Peneliti Penelitian ini dapat digunakan sebagai dasar penelitian terkait pekerjaan, pendidikan, pengetahuan dan sikap ibu terhadap gizi dengan kejadian sulit makan pada anak. Saran peneliti untuk penelitian selanjutnya perlu dilakukan penelitian untuk meneliti faktor lain seperti faktor ekternal sehingga hasil analisa penelitian menjadi lebih lengkap.

\section{DAFTAR PUSTAKA}

1. Adriana. (2011). Tumbuh kembang dan terapi bermain anak. Jakarta: Salemba Medika

2. Almatsier, S. (2009). Prinsip Dasar Ilmu Gizi. Jakarta : Penerbit PT Gramedia.

3. Anak di Indonesia. Jakarta: PT Gramidia Widiasarana Indonesia.

4. Andre. (2011). Pengaruh Lingkungan Sosial Terhadap Kejadian Picky Eater Pada Anak. Jurnal. Vol.3 No. 2

5. Apridji, (2011). Gizi Keluarga. Jakarta: Penerbit Swadaya.

6. Arikunto. (2007). Prosedur Penelitian Suatu Pendekatan Praktek. Jakarta: Rineka Aksara

7. Astuti. (2008). Hubungan Faktor Budaya Dengan Terjadinya Sulit Makan Pada Anak Di Tk Bakt II Surayabaya. StiKes Yarisis

8. Dani, M. (2011). Faktor-Faktor Yang Berhubungan Dengan Pendidikan Orang Tua Terhadap Sulit Makan Pada Anak. Jurnal Vol.4 No.3

9. DEPKES RI, (2013). Riset Kesehatan Dasar. Jakarta: Badan Penelitian dan Pengembangan Kesehatan Kementrian Kesehatan RI

10. Dharma, Kelana Kusuma. (2011). Metodologi Penelitian Keperawatan. Jakarta : Trans Info Media.

11. Eka, P. (2012). Hubungan Kebiasaan Makan Anak Terhadap Kejadian Sulit Makan Anak Di Desa Bangun Sari. Stikes Jambi

12. Febry. (2008). Buku Pintar Menu Balita. Jakarta : Wahyu Media.

13. Handayani (2013). Hubungan Sikap Ibu Dengan Kesulitan Makan pada Anak Usia Pra Sekolah di TK Barunawati II Jakarta Barat Tuhun 2006. UI

14. Harahap, Heryudarini. (2013). Masalah Gizi Mikro Utama dan Tumbuh Kembang

15. Hastono, Sutanto P. (2007). Analisis Data Kesehatan. Fakultas Kesehatan Masyarakat Universitas Indonesia.

16. Hendra, (2007). Kebiasaan Makan Anak Pra Sekolah di TK Negeri Pembina dan TK Islam AsySyakirin Jakarta Selatan. UIN

17. Hendra. (2015). Pengaruh Kurangnya Sikap Ibu Terhadap Gizi Baik Terhadap Sulit Makan Pada Anak Di Tk Bakti Jakarta Selatan. UI

18. Hidayat, (2007). Siapa Bilang Anak Sehat Pasti Cerdas. Jakarta : Gramedia.

19. Hidayat, A. Aziz Alimul. (2008) Pengantar Konsep Dasar Keperawatan. Jakarta: Salemba Medika

20. Imron. (2015). Hubungan Pendidikan Ibu Dengan Kesulitan Makan Pada Anak Pra Sekolah 3-5 Tahun Di Tk Leyangan Kebupaten Semarang. Jurnal Stikes Ngudi Waluyo 
21. Istiqomah, Nur. (2010). Faktor LingkunganSosial Yang Berhubungan Dengan Perilaku Anak Sulit Makan Usia Pra Sekolah Di Tk Raihanul Hamim Jakarta Selatan. Jurnal Universitas Pembangunan Nasional Veteran Jakarta

22. Judarwanto, W. (2015). Perilaku Makan Anak Sekolah. Jakarta. Klinik Khusus Makan Pada Anak.

23. Khumaidi M. (2008). Gizi Masyarakat. Dapertemen Pendidikan dan Kebudayaan, Direktoral Jendral Pendidikan Tinggi dan Pusat Antar Universitas Pangan dan Gizi IPB Bogor

24. Kurniasih, Dedeh, Hilmansyah, Marfuah Panji Astuti dan Saeful Imam. (2010). Sehat dan Bugar berkat Gizi Seimbang. Jakarta : Kompas Gramedia.

25. Kurniawaty. (2011). Hubungan Sikap Ibu Terhadap Gizi Dengan Sulit Makan Pada Anak Pra Sekolah Di Tk Al Hidayah Jakarta Selatan. UIN

26. Linda. (2011). Hubungan Pekerjaan Ibu Terhadap Kejadian Sulit Makan Pada Anak Pra Usia Sekolah Di Tk Aisyiyah. StiKes Gorontalo

27. Marmi, \& Rahardjo, K. (2012). Asuhan Neonatus, Bayi, Balita, dan Anak Prasekolah. Yogyakarta: Pustaka Belajar.

28. Maulana, Heri. (2009). Promosi Kesehatan Pada Anak .Jakarta : EGC.

29. Maulana. (2007). Menuju Anak Cerdas dan Sehat. Yogyakarta: AR. Russ Media Group.

30. Millah, K. (2013). Pengetahuan Ibu Dalam Mengatasi Prilaku Sulit Makan Anak di TK Al Hidayah Surabaya. StiKes Yarsis

31. Nirma. (2009). Hubungan Keyakinan (Agama) Terhadap Kebiasaan Makan Pada Anak Di Tk Cahaya Iman Martapura Kalsel. StiKes Lambung Mangkurat

32. Nita, (2010). Hubungan Sikap Ibu Terhadap Gizi dan Pola Makan Anak dengan Terjadinya Prilaku Sulit makan Pada Anak di Wilayah Kerja Puskesmas Kedungwungi II Kabupaten Pekalonan. Dakses tanggal 16 Mei 2016 From http:dx.doi.org/10.4236/aim.2010.36063

33. Notoadmodjo, S. (2010). Metodelogi Penelitian Kesehatan. Jakarta : Rineka Cipta.

34. Notoadmodjo, S. (2014). Ilmu Perilaku Kesehatan. Jakarta: Rineka Cipta.

35. Nurafriani. (2013). Hubungan Tingkat Pendidikan Ibu Dengan Kesulitan Makan Pada Anak Usia 3-5 Tahun Di Tk Perwanida Batu-Batu Kabupaten Soppeng. Jurnal Vol.3 No.4

36. Nursalam. (2008). Kunsep dan Penerapan Metodologi Penelitian Keperawatan. Jakarta.

37. Pratiwi. (2009). Pengaruh Lingkungan Sosial Terhadap Sulit Makan Pada Anak Usia Pra Sekolah Di Tk Husnul Yakin Semarang. Jurnal Vol. 4 No. 2

38. Purnawati, (2012) Faktor Ibu Yang Bekerja Terhadap Prilaku Sulit Makan Pada Anak Di Tk Ibnu Akbar Jakarta Selatan. FKIK UIN

39. Raditya, Karno. (2008). Posyandu dan Gizi Buruk di Indonesia. Diakses pada 23 mie 2016

40. Rahardjo. (2012). Berbagai Cara Pendidikan Gizi. Dapertemen Pendidikan dan kebudayaan Direktorat Jendral Pendidikan Tingkat Pusat antar Universitas Pangan dan Gizi Institut Pertanian Bogor.

41. Rosidi, H. (2012) Hubungan Pengetahuan Ibu Terhadap Kejadian Sulit Makan Pada Anak. Jurnal. Vol.5.No.2

42. Santoso, S, (2009). Status Gizi dan Tumbuh Kembang Anak . Jakarta :Raneka Cipta. 
43. Senduk, S. (2006). Pengelolan Keuangan Keluarga. Jakarta Gramedia

44. Setiadi. (2013). Konsep Dan Praktek Penulisan Riset Keperawatan, Edisi 2. Yugyakarta, Graha Ilmu

45. Sodhikin (2011). Asuhan Keperawaan Anak Gangguan Sistem Pencernaan dan Hepatobilier, Jakarta, Salemba Medika.

46. Soedibyo, (2008). Ilmu Gizi Untuk Praktisi Kesehatan. Yogyakarta: Graha Ilmu

47. Sukmawati. (2015). Hubungan Tingkat Pengetahuan Ibu Dengan Perilaku Sulit makan pada anak usia prasekolah 3-5 tahun di tk al amanah kecamatan sindang jaya kabupaten tanggerang. Jakarta : FKIK UIN

48. Supartini, Yupi. (2010). Buku ajar konsep dasar keperawatan anak. Jakarta: EGC.

49. Sutikno, Sobri. (2009). Mewujudkan SDM Yang Unggul. Yogyakarta: Araska

50. Waryana. (2010). Gizi Seimbang. Yogyakarta : Pustaka Rihama

51. Wawan, A dan Dewi, M. (2010). Teori dan Pengukuran Pengetahuan, Sikap dan Perilaku Manusia. Yogyakarta : Nuha Medika.

52. Widya Karya Nasional Pangan dan Gizi. (2012). Prinsip dasar Ilmu Gizi. Jakarta: PT Gramedia Pustaka Utama.

53. Widyarini, (2013). Relasi Orang Tua Dan Anak. Jakarta : PT Elex Media Komputindo.

54. Winarsho, E, (2009). Agar Si Kecil Mau Makan. Yogyakarta : In Azna Books

55. Wirdha, U. (2013). Kebiasaan Makan Anak Berhubungan Dengan Perilaku Sulit Makan Pada Anak Usia Pra Sekolah di TK Putra II dan TK Al Wildan. UI

56. Yusuf, Syamsu, (2012). Psikologi Perkembangan Anak dan Remaja. Bandung : Remaja Rosdakarya.

57. Zainil, Abidin. (2013). Faktor kebiasaan anak yang buruk terhadap sulit makan pada anak. UNIMUS 